УДК 543.573:662.63

DOI https://doi.org/10.15673/swonaft.v84i1.1862

\title{
ТЕРМІЧНА ДЕСТРУКЦІЯ ГРАНУЛЬОВАНОГО ПАЛИВА 3 МІСКАНТУСА
}

\author{
Корінчевська Т.В., канд. техн. наук, Михайлик В.А., канд. техн. наук, с.н.с. \\ Інститут технічної теплофізики НАН України, м. Київ
}

\begin{abstract}
Анотація. Плантації енергетичних культур (верба, тополя, міскантус та ін.) забезпечують виробництво не тільки ефективного біопалива, а й поліпшують екологічний стан довкілля за рахунок інтенсивного поглинання вуглекислого газу з атмосфери. Ефективною сировиною для виробництва твердого біопалива $\epsilon$ міскантус. В статті представлені результати термічного аналізу біопалива з міскантуса та дослідження щзодо впливу на термічну деструкцію гранульованого палива фракційного складу сировини, температури $i$ тиску гранулювання. В роботі використані зразки гранул, отримані при холодному пресуванні, механоактивації та термічній активації сировини. Методами термогравіметрії та диференційного термічного аналізу визначено температурні інтервали зневоднення, термічного розкладання органічних і мінеральних речовин, середні швидкості термічного розкладання органічних сполук, вологість та зольність зразків біопалива. Для всіх зразків гранульованого палива з міскантуса характерні стадї зневоднення, термічного розкладання органічних сполук, щуо супроводжується видаленням газоподібних продуктів, та розкладання мінеральних речовин. Найбільша швидкість виходу газоподібних речовин спостерігалась у гранул з механоактивованої та термічно активованої сировини, найменша - у гранули з полідисперсної фракиї після холодного пресування. Було встановлено, щзо механоактивачія і термічна активачія сировини впливають на процес термічної деструкції - збільшується інтенсивність розкладання органічних речовин. Виявлено, щзо механоактивація сировини є найбільш суттєвим фактором впливу на кінетику термодеструкиіі. Під час термічного розкладання гранул, переважно з термічною активацією матеріалу в процесі гранулювання, у високотемпературному періоді розкладання спостерігалися мікровибухи.
\end{abstract}

Ключові слова: дериватографія, термічна деструкція, біопаливо, міскантус, гранулювання, активація сировини.

\section{THERMAL DECOMPOSITION OF GRANULATED FUEL FROM MISCANTUS}

\author{
Korinchevska T.V., Ph.D., Mykhailyk V.A., Ph.D., Senior Research Scientist \\ Institute of Engineering Thermophysics of the National Academy of Sciences of Ukraine, Kyiv
}

\begin{abstract}
The plantations of energy crops (willow, poplar, miscanthus, etc.) ensure the production not only of efficient biofuels, but also improve the ecological state of the environment due to the intensive absorption of carbon dioxide from the atmosphere. Miscanthus is an effective raw material for the production of solid biofuels. The article presents the results of thermal analysis of biofuel from miscanthus and research on the influence of the fractional composition of raw materials, temperature and pressure of granulation on the thermal destruction of granular fuel. Samples of granules obtained by cold pressing, mechanical activation and thermal activation of raw materials are used in the work. Temperature intervals of dehydration, thermal decomposition of organic and mineral substances, average rates of thermal decomposition of organic compounds, humidity and ash content of biofuel samples were determined by thermogravimetry and differential thermal analysis. Stages of dehydration, thermal decomposition of organic compounds, accompanied by the removal of gaseous products, and decomposition of mineral substances are characteristic of all samples of granular fuel from miscanthus. The highest rate of release of gaseous substances was observed in granules from mechanically activated and thermally activated raw materials, the lowest - in granules from polydisperse fraction after cold pressing. It was found that mechanical activation and thermal activation of raw materials have an effect on the process of thermal destruction. The intensity of decomposition of organic matter increases. It was found that the mechanical activation of raw materials is the most significant factor influencing the kinetics of thermal destruction. In the granules, mainly with thermal activation of the material in the
\end{abstract}




\section{Одеська національна академія харчових технологій ТЕОРЕТИЧНІ ТА ЕКСПЕРИМЕНТАЛЬНІ ДОСЛІДЖЕННЯ ГІДРАВЛІЧНИХ, ТЕПЛОВИХ ТА МАСООБМІННИХ ПРОЦЕСІВ}

granulation process, microexplosions were observed in the high-temperature decomposition period during thermal destruction.

Key words: derivatography, thermal destruction, biofuel, miscanthus, granulation, activation of raw material.

Аналіз останніх досліджень та публікацій. Екологічний стан довкілля потребує термінових заходів для його покращення. Одним 3 важливих кроків є заміщення традиційних вуглеводневих енергоресурсів відновлюваними джерелами енергії. Оскільки Україна - аграрна країна, то перспективним напрямком розвитку відновлюваної енергетики є біоенергетика [1]. Використання біомаси як біопалива дозволить значно знизити викиди парникових газів.

Для виготовлення біопалива використовують не тільки деревину та відходи іiі переробки, відходи сільськогосподарського виробництва, а й сировину зі спеціальних енергоплантацій. В ряді розвинутих країн, спираючись на положення Кіотського протоколу, широко проводять дослідження та створюють енергоплантації, які забезпечують виробництво не тільки ефективного біопалива, а й інтенсивно поглинають вуглекислий газ з атмосфери [2].

Як енергокультури на таких плантаціях найчастіше вирощують вербу, тополю та міскантус. Міскантус $\epsilon$ одною 3 найбільш вигідних культур 3 погляду на вихід 3 гектару чистої енергії [2]. Він має хорошу врожайність сухої біомаси (до 25 т/га), високу теплотворну здатність (до 18 МДж/кг) та низьку природну вологість (до $25 \%$ ), що робить його ефективною сировиною для виробництва твердого біопалива [1]. За хімічним вмістом міскантус подібний до деревини. В залежності від різновиду культури він містить $40-$ $60 \%$ целюлози, 20 - 40 \% геміцелюлози та 10 - $15 \%$ лігніну [3].

В літературі є досить значна кількість публікацій результатів досліджень присвячених термічним характеристикам міскантуса як біопалива [4-8]. Проте, мало робіт по термічній деструкції виконано безпосередньо на паливі в гранульованому стані, не досліджено вплив різних технологій підготовки сировини до гранулювання на якість палива. Відомо, що на процес гранулювання впливає ряд факторів - вологість, температура і тиск гранулювання, фракційний склад сировини та ін. За рахунок цих факторів сировина набуває властивостей, необхідних для виготовлення гранул. Встановлено, що при зміні фізико-механічних факторів отримання гранул може змінюватися хімічний склад біомаси [9]. Зокрема активуються внутрішні зв'язуючі речовини (лігнін), що суттєво впливають на механічну якість гранул.

Мета та основні завдання роботи. Мета - дослідити вплив активації сировини на термічну деструкцію гранул з міскантуса. Для досягнення мети були поставлені та вирішені наступні завдання: підготувати зразки гранульованого біопалива; дослідити термічне розкладання гранул та визначити температурні інтервали зневоднення, термічного розкладання органічних і мінеральних речовин, вологість та зольність палив; проаналізувати кінетику термічного розкладання органічних речовин; виявити вплив на термічну деструкцію гранульованого палива холодного пресування, механоактивації та термічної активації сировини.

Матеріали і методи досліджень. Стебла міскантуса подрібнювали та розділяли на ситах, отримані фракції - полідисперсну (ПД), яка включає всі можливі розміри частинок в діапазоні 0,2 - 3 мм, крупну (КФ) 3 розміром частинок $2-3$ мм та мікрофракцію (МФ) з розміром частинок $\leq 0,2$ мм використовували для отримання гранул. Гранули виробляли за допомогою спеціального пристрою, що складається 3 розбірної матриці та пуансона. Пресування здійснювали на адаптованій до стискання розривній машині типу МР 100 за тиску 100 - 120 МПа. В результаті отримували експериментальні гранули в вигляді таблеток діаметром 8 мм та висотою 2,5 - 3,0 мм.

Щоб оцінити вплив активації сировини на термічне розкладання гранул були підготовлені зразки, отримані при: 1) холодному пресуванні (ХП), при якому в результаті дії високого тиску (100 - 120 МПа) за температур зовнішнього середовища $\left(\sim 20{ }^{\circ} \mathrm{C}\right)$ активізуються контактні центри матеріалу; 2) механоактивації (MA), яка досягається шляхом подрібнення сировини до розміру частинок $\leq 0,2$ мм; 3 ) термічній активації (ТА), коли подрібнену сировину пресували за допомогою прогрітих до $150{ }^{\circ} \mathrm{C}$ матриці та пуансона.

Якість біопалива визначається вологістю, теплотворною здатністю, зольністю, вмістом домішок та летючих речовин [9]. Більшість з цих показників можна визначити методами термогравіметрії та диференційного термічного аналізу.

Дослідження проведено в модернізованому в ІТТФ НАН України дериватографі Q-1000 системи РaulikPaulik-Erdey (фірма «МОМ», Угорщина) в діапазоні $20-1007{ }^{\circ} \mathrm{C}$ при швидкості нагрівання 7,4 K/хв. Зразки розміщували в відкритий конічний платиновий тигель за схемою, наведеною в [10]. Інертною речовиною в тиглі порівняння був оксид алюмінію. Корекцію температурної шкали виконували за температури переходу кварцу з $\alpha$ - в $\beta$-форму $\left(573{ }^{\circ} \mathrm{C}\right)$. Відхилення температури не перевищувало $\pm 0,5$ К. Збір та обробка інформації здійснювались за допомогою розробленої прикладної комп’ютерної програми «Derivatograph». В ході дослідження реєстрували температуру (Т), масу зразка (ТГ), швидкість зміни маси (ДТГ) та тепловий ефект (ДТА), які відображались в вигляді кривих. Співставлення кривих ДТГ та ТГ дає можливість точно визначити температурні інтервали відповідних процесів термічного розкладання та робити їх кількісну оцінку.

Наукові праці, Том 84, випуск 1

Scientific Works, Volume 84, Issue 1 
Одеська наиіональна академія харчових технологій

\section{ТЕОРЕТИЧНІ ТА ЕКСПЕРИМЕНТАЛЬНІ ДОСЛІДЖЕННЯ ГІДРАВЛІЧНИХ, ТЕПЛОВИХ ТА МАСООБМІННИХ ПРОЦЕСІВ}

Результати досліджень. Термічному аналізу були піддані гранули, виготовлені холодним пресуванням полідисперсної фракції (рис. 1), отримані термічною активацією сировини, 100 (рис. 2) та 30 \% (рис. 4) якої було попередньо механоактивовано, та виготовлені холодним пресуванням з сировини, 30 \% якої було піддано механоактивації.

Для всіх зразків гранул біопалива (рис. 1 - 4) характерні стадії видалення води, термічного розкладання органічних та мінеральних речовин.

Оскільки гранули мали досить низьку вологість 5 - 9 \% (табл. 1), то видалення води супроводжувалось невеликими ендотермічними піками на кривих ДТА в діапазоні від температури навколишнього середовища, до температури повного зневоднення, яка залежить від складу та умов отримання гранул і варіюється в межах $171-179^{\circ} \mathrm{C}$ (табл. 1, рис. 1 - 4). Швидкість процесу дегідратації матеріалу (криві ДТГ) в ході програмованого нагрівання зразка проходить через максимум і в подальшому зменшується практично до нульового значення.

Таблиия 1

Результати аналізу термодеструкції зразків гранул біопалива з міскантуса

\begin{tabular}{|c|c|c|c|c|c|c|c|c|}
\hline \multirow{3}{*}{$\begin{array}{l}\text { № } \\
\text { 3/ח }\end{array}$} & \multirow{3}{*}{$\begin{array}{l}\text { Склад та умови отриман- } \\
\text { ня гранул }\end{array}$} & \multirow{2}{*}{\multicolumn{2}{|c|}{ Видалення води }} & \multicolumn{4}{|c|}{ Термічне розкладання речовин } & \multirow{3}{*}{\begin{tabular}{|c|} 
Зола \\
$\%$ \\
CM
\end{tabular}} \\
\hline & & & & \multicolumn{2}{|c|}{ органічних } & \multicolumn{2}{|c|}{ мінеральних } & \\
\hline & & $\begin{array}{l}\text { інтер- } \\
\text { вал, } \\
\quad{ }^{\circ} \mathrm{C}\end{array}$ & $\begin{array}{l}\text { вологість, } \\
\%\end{array}$ & $\begin{array}{l}\text { інтервал, } \\
{ }^{\circ} \mathrm{C}\end{array}$ & $\begin{array}{l}\text { вміст, } \\
\% \text { СМ }\end{array}$ & $\begin{array}{l}\text { інтервал, } \\
{ }^{\circ} \mathrm{C}\end{array}$ & $\begin{array}{l}\text { вміст, } \\
\% \text { CM }\end{array}$ & \\
\hline 1 & ПД фракція. ХП & $20-171$ & 8,68 & $187-525$ & 93,04 & $525-1007$ & 0,99 & 5,97 \\
\hline 2 & МФ. ТА & $23-179$ & 5,63 & $179-525$ & 96,27 & $525-1007$ & 0,25 & 3,48 \\
\hline 3 & $30 \%$ МФ та $70 \%$ КФ. ХП & $20-177$ & 7,22 & $177-528$ & 95,27 & $528-1006$ & 0,10 & 4,63 \\
\hline 4 & $30 \%$ МФ та $70 \%$ КФ. ТА & $19-176$ & 7,78 & $176-526$ & 95,02 & $526-1001$ & 0,29 & 4,69 \\
\hline
\end{tabular}

Після зневоднення спостерігається термічне розкладання органічних речовин матеріалу, що супроводжується зміною маси зразка та тепловиділенням. Температури початку термічного розкладання та повного зневоднення співпадають. Завершення процесу розкладання органічних речовин визначається відсутністю тепловиділення та практично незмінністю маси зразка при подальшому зростанні температури (криві ТГ та ДТА). Стадію термічного розкладання органічних речовин умовно можна розділити на низько- та високотемпературний періоди. В досліджених зразках ці періоди явно розділені зниженням швидкості розкладання та спадом тепловиділення. На стадії термічного розкладання органічних речовин відбувається вихід газоподібних продуктів, що утворюються при розкладанні геміцелюлози, целюлози та лігніну. Максимальна швидкість їх виділення спостерігається при $272-289^{\circ} \mathrm{C}$ і залежить від умов отримання гранул.

На завершальній стадії нагрівання після завершення газовиділення відбувається розкладання деяких термічно нестійких мінеральних речовин, що містяться в стеблах міскантуса. Вміст золи в дослідженому біопаливі $(\sim 3,5-6 \%)$ виявився вищим, ніж у гранул з деревини сосни (зазвичай не більше $1 \%)$ [10], що пояснюється значно більшим вмістом мінеральних речовин в стеблах міскантуса.

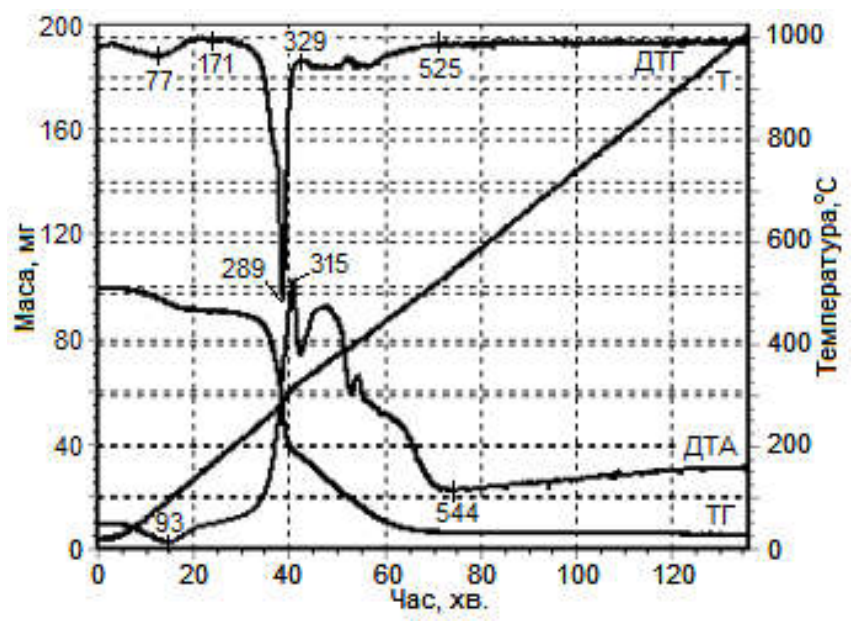

Рис. 1 - Дериватограма гранули з ПД фракції міскантуса. ХП

\footnotetext{
Наукові праці, Том 84, випуск 1
} 
В гранулі з полідисперсного матеріалу, виготовленої методом холодного пресування (рис. 1, табл. 1) повна дегідратація відбувається в інтервалі температур $20-171{ }^{\circ} \mathrm{C}$. Максимальна швидкість видалення води реєструється при $77^{\circ} \mathrm{C}$. Термічне розкладання органічних речовин відбувається в інтервалі $171-525^{\circ} \mathrm{C}$. Добре виражені низькотемпературний $\left(171-329{ }^{\circ} \mathrm{C}\right)$ та високотемпературний $\left(329-525{ }^{\circ} \mathrm{C}\right)$ періоди. В низькотемпературному періоді матеріал гранули стрімко деградує, спостерігається висока швидкість розкладання з максимальним значенням при $289^{\circ} \mathrm{C}$ та потужне зростання тепловиділення, яке досягає максимуму при $315^{\circ} \mathrm{C}$. Для високотемпературного періоду характерне зменшення швидкості розкладання органічних речовин та тривале тепловиділення на досить високому рівні, яке є наслідком розкладання целюлози та лігніну, що мають більш високу теплотворну здатність в порівнянні з геміцелюлозою [11]. Подальше зростання температури (до $1007^{\circ} \mathrm{C}$ ) викликає незначну зміну маси.

Попередня механоактивація 100 \% сировини та термічна активація в процесі пресування (рис. 2, табл. 1) зміщує початкову температуру розкладання (і відповідно температуру кінця зневоднення) на $8{ }^{\circ} \mathrm{C}$ в область більш високих температур. Кінцева температура розкладання залишається незмінною. Низькотемпературний період розкладання органічних речовин звужується на $13{ }^{\circ} \mathrm{C}$, при цьому температура максимуму швидкості розкладання зміщується на $9{ }^{\circ} \mathrm{C}$ в область більш низьких температур порівняно зі зразком, отриманим холодним пресуванням (рис. 1). Також спостерігається зміщення на $10^{\circ} \mathrm{C}$ температури максимуму тепловиділення в область більш низьких температур. Крива ДТА на стадії термічного розкладання характеризується стрімким наростанням та спаданням тепловиділення.

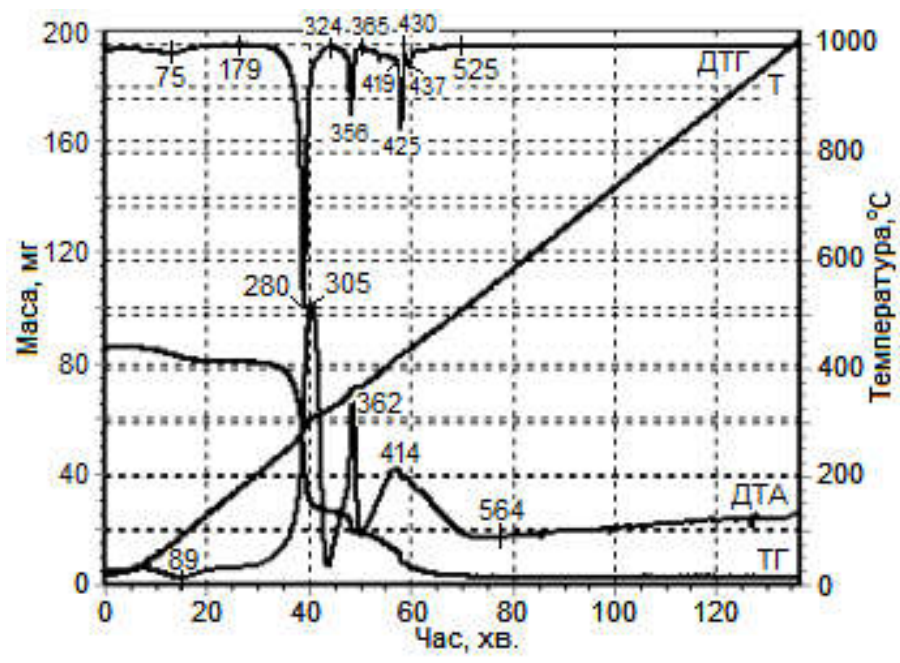

Рис. 2 - Дериватограма гранули з МФ міскантуса. ТА

Зменшення вмісту МФ до 30 \% при ХП (рис. 3, табл. 1) зрушує початкову температуру розкладання органічних речовин на $2{ }^{\circ} \mathrm{C}$ в область більш низьких температур та кінцеву температуру розкладання на $3{ }^{\circ} \mathrm{C}$ в область більш високих температур.

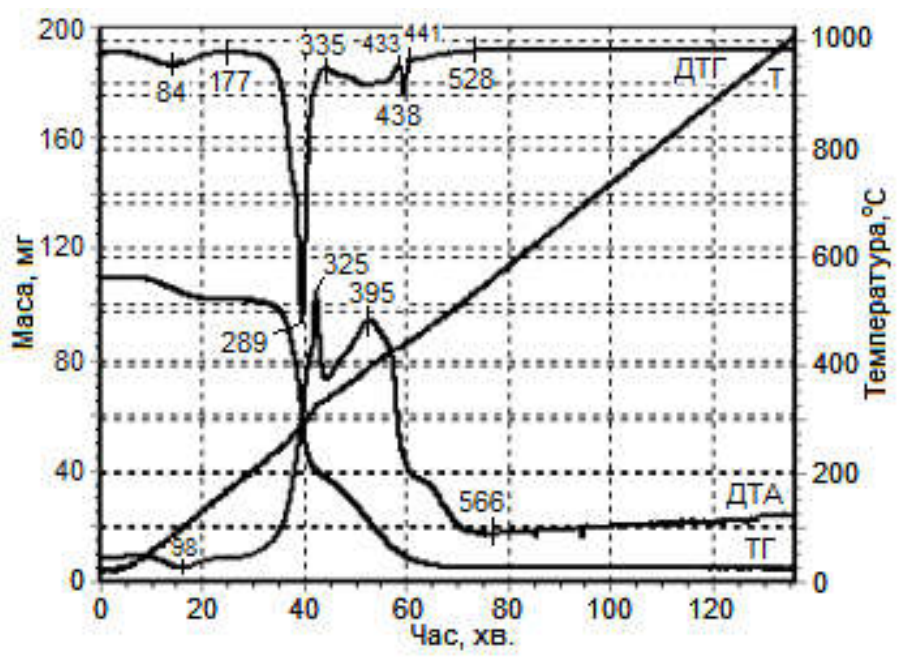

Рис. 3 - Дериватограма гранули з 30\% МФ та 70\% КФ міскантуса. ХП 
Одеська національна академія харчових технологій

\section{ТЕОРЕТИЧНІ ТА ЕКСПЕРИМЕНТАЛЬНІ ДОСЛІДЖЕННЯ ГІДРАВЛІЧНИХ, ТЕПЛОВИХ ТА МАСООБМІННИХ ПРОЦЕСІВ}

Разом 3 цим розширюється період низькотемпературного розкладання. Характер кривих ДТА подібний зі зразком виготовленим з ПД фракції міскантуса (рис. 1), проте спостерігається більш інтенсивне тепловиділення в високотемпературному періоді розкладання.

Термічна активація суміші 30 \% МФ 370 \% КФ (рис. 4, табл.1) має незначний вплив на процес розкладання органічних речовин - спостерігається звуження інтервалу розкладання на $1{ }^{\circ} \mathrm{C}$ (крива ДТГ). Проте аналіз кривої ДТА показує, що максимуми тепловиділення і теплопоглинання зміщуються в область більш високих температур та реєструється зниження інтенсивності тепловиділення в високотемпературній стадії розкладання.

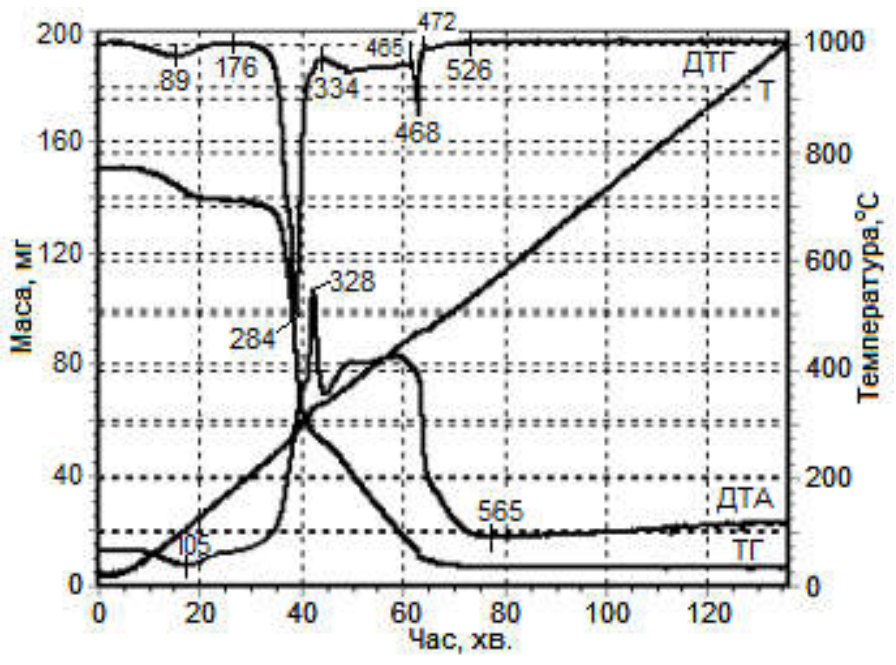

Рис. 4 - Дериватограма гранули з 30\% МФ та 70\% КФ міскантуса. ТА

Аналіз кінетики термічного розкладання органічних речовин (табл. 2) дає можливість оцінити вплив механоактивації та термічної активації на термічну деструкцію гранул з міскантуса. Для всіх зразків у низькотемпературному періоді спостерігалась висока інтенсивність розкладання, вона у $3,1-3,8$ рази перевищувала таку в високотемпературному періоді. Найбільша швидкість виходу газоподібних речовин у низькотемпературному періоді спостерігалась у гранули, яка на 100 \% складається з МФ після ТА, найменша - у гранули 3 ПД фракції після ХП (табл. 2). Отже, і механоактивація, і термічна активація збільшують інтенсивність розкладання органічних речовин в низькотемпературному періоді, проте за даних умов можна зробити висновок, що механоактивація впливає більш суттєво.

Таблиия 2

Кінетика термічного розкладання органічних сполук гранульованого біопалива 3 міскантуса

\begin{tabular}{|c|c|c|c|c|c|c|c|c|c|}
\hline \multirow{3}{*}{$\begin{array}{l}\text { № } \\
3 / \Pi\end{array}$} & \multirow{3}{*}{$\begin{array}{l}\text { Склад та умови отриман- } \\
\text { ня гранул }\end{array}$} & \multicolumn{4}{|c|}{ Втрата маси } & \multicolumn{4}{|c|}{$\begin{array}{c}\text { Швидкість розкладання органічних } \\
\text { сполук }\end{array}$} \\
\hline & & \multicolumn{2}{|c|}{$\begin{array}{l}\text { низькотем- } \\
\text { пературний } \\
\text { період }\end{array}$} & \multicolumn{2}{|c|}{$\begin{array}{c}\text { високотемпе- } \\
\text { ратурний } \\
\text { період }\end{array}$} & \multicolumn{2}{|c|}{$\begin{array}{c}\text { низькотем- } \\
\text { пературний } \\
\text { період }\end{array}$} & \multicolumn{2}{|c|}{$\begin{array}{l}\text { високотемпе- } \\
\text { ратурний пе- } \\
\text { ріод }\end{array}$} \\
\hline & & МГ & $\%$ & МГ & $\%$ & мг/хв. & $\begin{array}{c}\% \\
\mathrm{CM} / \mathrm{xB} .\end{array}$ & $\mathrm{M} \Gamma / \mathrm{XB}$ & $\begin{array}{c}\% \\
\mathrm{CM} / \mathrm{xв}\end{array}$ \\
\hline 1 & ПД фракція. ХП & 55,6 & 61,44 & 28,6 & 31,60 & 3,08 & 3,41 & 0,98 & 1,08 \\
\hline 2 & МФ. ТА & 54,0 & 67,16 & 23,4 & 29,10 & 3,09 & 3,85 & 0,82 & 1,02 \\
\hline 3 & $30 \%$ МФ та $70 \%$ КФ. ХП & 63,9 & 62,96 & 32,8 & 32,32 & 3,61 & 3,56 & 1,14 & 1,12 \\
\hline 4 & $30 \%$ МФ та $70 \%$ КФ. ТА & 86,0 & 62,0 & 45,8 & 33,02 & 4,90 & 3,54 & 1,59 & 1,15 \\
\hline
\end{tabular}

Результати досліджень свідчать, що більша частина теплоти термічного розкладання органічних речовин гранульованих палив вивільняється у високотемпературному періоді при швидкості розкладання від 1,02 до $1,15 \% \mathrm{CM} /$ хв.

На відміну від гранул отриманих ХП (рис. 1), у гранулах, переважно з ТА матеріалу (рис. 2 та 4), при термічному розкладанні в інтервалі температур $320-440{ }^{\circ} \mathrm{C}$ спостерігалися мікровибухи, реєстрація яких відбувалась на кривих ТГ, ДТГ та ДТА. Мікровибухи супроводжувались викидами частини зразка за межі тигля. Незначний мікровибух спостерігався також під час термічного розкладання гранули, отриманої холо-

Наукові праці, Том 84, випуск 1

Scientific Works, Volume 84, Issue 1 


\section{Одеська національна академія харчових технологій ТЕОРЕТИЧНІ ТА ЕКСПЕРИМЕНТАЛЬНІ ДОСЛІДЖЕННЯ ГІДРАВЛІЧНИХ, ТЕПЛОВИХ ТА МАСООБМІННИХ ПРОЦЕСІВ}

дним пресуванням (рис. 3). Мікровибухи завжди спостерігались після різкого зростання температури в результаті тепловиділення.

Найбільш виразно послідовність процесів, що відбуваються при двох мікровибухах, представлено дериватограмою на рис. 2. Перший мікровибух відбувся в інтервалі $324-365{ }^{\circ} \mathrm{C} 3$ максимумом швидкості при $356{ }^{\circ} \mathrm{C}$, другий - в інтервалі $419-430{ }^{\circ} \mathrm{C}$ з максимумом швидкості при $425{ }^{\circ} \mathrm{C}$ (крива ДТГ). 3 кривої ДТА добре видно, що обом мікровибухам передувало стрімке наростання температури: першому - 322 до 362 ${ }^{\circ} \mathrm{C}$, другому - 367 до $414{ }^{\circ} \mathrm{C}$. Третій незначний мікровибух зареєстровано в інтервалі $430-442{ }^{\circ} \mathrm{C} 3$ максимумом швидкості при $437^{\circ} \mathrm{C}$.

Оскільки наявність мікровибухів, що супроводжуються виносом частини зразка, може викликати складнощі при спалюванні гранульованого біопалива 3 міскантуса в топках з розділеним процесом спалювання, то при виготовленні гранул потрібно уникати термічної активації та повної механоактивації сировини перед гранулюванням.

У зв'язку з втратою матеріалу гранул під час мікровибухів потребують незначного корегування величини вмісту мінеральних речовин, що термічно розкладаються, та золи (табл. 1), а також середньої швидкості термічного розкладання органічних речовин в високотемпературному періоді (табл. 2) для зразків гранул, що представлені дериватограмами на рис. 2 - 4.

Висновки. Методами термогравіметрії та диференціально-термічного аналізу виконано дослідження термічного розкладання гранульованих біопалив зі стовбурів міскантуса. Визначено температурні інтервали зневоднення, термічного розкладання органічних і мінеральних речовин, вологість та зольність палив. Визначено, що швидкість та температурний інтервал термічного розкладання гранульованих палив залежить від способу активації біосировини. У гранулах, переважно з термічною активацією матеріалу, при термічному розкладанні в інтервалі температур $320-440^{\circ} \mathrm{C}$ спостерігалися мікровибухи, що супроводжувались втратою частини зразка. У зв'язку з цим потрібно враховувати, що наявність мікровибухів при термічному розкладанні гранул з міскантусу може бути причиною порушення режиму газифікації в топках 3 розділеним процесом спалювання та виносом частини палива за межі топкового пристрою.

\section{References}

1. Royik, M.V., Hanzhenko, O.M. (2015). Ahropromyslovi enerhetychni plantatsiyi — shlyakh do enerhonezalezhnosti Ukrayiny. Ahroprofi: ukr. tyzhnevyk dilovoyi informatsiyi. Retrieved from http://www.agroprofi.com.ua/statti/1297-agropromislovi-energetichni-plantatsiji-shlyakh-doenergonezalezhnosti-ukrajini.

2. Kuptsov, N.S., Popov, E.G. (2015). Energoplantatsii. Spravochnoe posobie po ispolzovaniyu energeticheskih rasteniy. Minsk: Konfido.

3. Iastremska, L. S., Pryshliak, R. I., Fedoniuk, Yu. V. (2017). Miskantus - enerhetychna kultura dlia otry-mannia biopalyva. Problemy ekolohichnoi biotekhnolohii, 1. Retrieved from http://nbuv.gov.ua/UJRN/peb_2017_1_3.

4. Collura, S., Azambre, B., Weber, J. (2005). Kinetic modelling of the pyrolysis of Miscanthus $\times$ Giganteus from the thermogravimetric analysis of its fractionated components. Environmental Chemistry Letters, 3, 95-99. doi:10.1007/s10311-005-0007-0.

5. Brosse, N., Dufour, A., Meng, X., Sun, Q., Ragauskas, A. (2012). Miscanthus: a fast- growing crop for biofuels and chemicals production. Biofuels, Bioproducts and Biorefining, 6(5), 580-598. doi:10.1002/bbb.1353.

6. Kok, M.V., Özgür, E. (2013). Thermal analysis and kinetics of biomass samples. Fuel Processing Technology, 106, 739-743. doi:10.1016/j.fuproc.2012.10.010.

7. Jeguirim, M., Dorge, S., Loth, A., Trouvé, G. (2010). Devolatilization kinetics of miscanthus straw from thermogravimetric analysis. International Journal of Green Energy, 7(2), 164-173. doi:10.1080/15435071003673641.K

8. Hideno, A. (2018). Thermal degradation behavior of ball-milled Miscanthus plants and its relationship to enzymatic hydrolysis. BioResources, 13(3), 6383-6395. doi:10.15376/biores.13.3.6383-6395

9. Malik, B., Pirzadah, T., Islam, S., Tahir, I., Kumar, M., Rehman, R. (2015). Biomass pellet technology: A green approach for sustainable development. In: K. Hakeem, M. Jawaid, O.Y. Alothman (Eds.), Agricultural Biomass Based Potential Materials (pp. 403-433). Springer, Cham. doi:10.1007/978-3-319-13847-3_19.

10. Mykhailyk, V.A., Snezhkin, Yu.F., Korinchuk, D.M. (2014). Termichne rozkladannia hranul palyva na osnovi torfu ta derevyny. Promyishlennaya teplotehnika, 36(2), 13-21.

11. Mykhailyk, V.A., Korinchevska, T.V., Korinchuk, D.M., Dakhnenko, V.L. (2019). Termichnyi analiz hranulovanoho biopalyva torrefikovanoho u atmosferi vlasnoho hazopodibnoho seredovyshcha. Teplofizyka ta teploenerhetyka, 41(4), 70-77.

Отримано в редакцію 11.06.2020

Прийнято до друку 17.09.2020
Received 11.06.2020

Approved 17.09.2020 